\title{
Study on the Cultivate Social Adapt Ability of Poor College Students
}

\author{
ChangXiang.Jiang
}

\author{
Jiangxi Science \& Technology Normal University, Nanchang, Jiangxi, 330013, P.R. China
}

MAME2013@163.com

Keywords: Poor College Students, social adaptation, Ability.

\begin{abstract}
The existence of poor college students living environment and ordinary undergraduates are some differences, in the late into the community, students may not meet the social situation arise. In this paper, based on analysis of the actual situation of poor college students, focused on the method of how to cultivate and improve students' ability to adapt to society, and the integration of economic and spiritual poverty are two methods to create a high-quality higher education environment. When college students improve poor social adaptation, the need for a comprehensive analysis of the family, school, self and other factors, to understand what factors will affect social adaptation college students, college students to accelerate the speed of social integration.
\end{abstract}

\section{Introduction}

The basic goal of higher education is to provide sufficient high-quality personnel for social development, so that students can better serve the community. But in recent years after a poor college students into the community, there is a problem often can not adapt to the working environment, so after students enter the workplace, how to change the concept, to adapt to the needs of social development, the correct values and career outlook has become evaluate colleges an important factor in education levels. In this paper, according to the actual situation of poor college students of social adaptability analysis on how to strengthen the social adaptability college students to discuss, to provide reference for improving the level of training colleges social adaptability.

\section{Situation social adaptability Poor College Students}

According to Ministry of Education statistics, in 1996 our poor college students has reached 100 million, while in 2000 the rapid increase to 145 million in 2010 has reached 300 million, a very fast growth in the number of poor students, the proportion of up to $15 \%-35 \%$, while the poor students in the proportion of poor students also followed the growth, about $6.2 \%-16 \%$, showing a rapid growth trend.

Social adaptability is the role of students and society, students and their ability to regulate the capacity. Long-term students in poverty, compared with ordinary university student educational environment, there are some shortcomings, knowledge of environmental impact by life, come into contact with the narrow range of less interpersonal, and parents are not well educated, can not provide a good home education. In this environment, the growth of college students, although some get through university education knowledge grows, but poor social skills, after entering social work, often not suited to the situation. According to Youth Foundation survey found that college students in poverty, about 74.5 percent of the students are not satisfied with the status quo of life, while $65.3 \%$ of students did not understand the joy of life, there are $53.4 \%$ of the students thought of depression or psychological tendencies. According to statistics found that college students of extreme events in recent years, there are about $52.8 \%$ of the students in economic difficulties, and psychological state of the majority of poor college students, there are some problems, mainly as introverted, anxious, sensitive, self-esteem, withdrawn and so on. 


\section{The importance of social adaptability training Poor College Students}

Improve social adaptability students, has become a national necessity to build a modern society needs. In the 21 st century as a new era of rapid economic development, economic structure from traditional capital, and gradually transition to a knowledge of the economic structure, in this environment, the demand for talents also rising. In order to develop a comprehensive high-quality personnel, the need to strengthen social resilience of poor college students, so that students after graduation, you can quickly enter the working state of flux. American scholars have proposed, in the process of national development, talent is the basis of modern nation-building elements, as well as one of the most important factors. If the personnel system and the lack of ability to adapt to the environment, did not accept this change from psychology, it will lead to thoughts, attitudes, behavior change can not be completed modernization, development and lead to students unable to survive in society. Even the late management system is very advanced, with no suitable talent were, then will become useless pile of paper, therefore, in order to realize the modernization of our country, we must pay attention to cultivate social adaptation ability, so that students develop a the right mental attitude, lifestyle, career outlook and values. Theoretically, knowledge, institutions, science and technology can be classified as material basis, these foundations can create a lot of wealth for the community, but must be used by qualified personnel, can really play the role of a material basis. College students, as China's most important youth talent pool resources, their social adaptation, directly determines the social development and progress, to achieve the great rejuvenation of China has a very important role.

\section{Poor college students social skills training program}

\subsection{Financial assistance with self-reliance}

In order to give full play to the actual effectiveness of the school funding system, the university needs to be optimized handling, award, cut, fill-funded projects such as the use of the process will be combined with each other funded projects, changing to "fill" the main funding model, but take Award fill, loan and other means, additional self scholarships, grants and scholarships to increase efforts to conduct assessment activities once a year, and for outstanding students to help with publicity. Provide stability for poor students study jobs, and with the national student loan method to reduce over-reliance on poor college students psychological school grants, to help students in schools of social work and lay into the psychological basis, so that students can better integrate into society .

\subsection{Work-study program with the Talent Education}

Schools should encourage students to participate in work-study activities, and by helping the school to ensure that labor and service income students can get deserved. Work-study activity can improve poor college students fighting spirit to help students develop the attitude of self-improvement efforts, and to help students gain practical experience in community-based, so that students get the ability to effectively improve social practice. Professional school students need to increase compliance with this professional and technical positions, students completing the foundation of learning, can get out of school early, try to work in the enterprise among the professional and college students to work in conjunction with each other, so that students can practice their learning on the job to knowledge.

\subsection{Thanksgiving education with social knowledge}

Universities need to play out their social influence, with the media about the actual situation of poor college students to the community, to attract businesses, organizations and individuals funded students with difficulties. In the process of funding, the school requires students to be thankful for education to help students develop positive attitudes and social returns. Obligations such as student tutoring underprivileged students, through their knowledge, to provide help for other economic difficulties vulnerable groups. By goodwill activities so that students can experience the joy of 
helping others, the warmth along with others, to improve their social adaptation of hope in the transmission process.

\subsection{With enhanced social responsibility practice}

Training of personnel in the course of the school, students need not only knowledge, but also need to develop students character, ability, moral and social responsibility, and college students in order to get a better space for development in society, but also need these qualities as support. Social practice as an important social adaptability training method can not only verify the theoretical knowledge of student learning, the method can also help students learn how to analyze and solve problems, so that students learn to truly master the knowledge. Through social practice, you can make poor college students from psychological dependence, improve self-reliance, so that students understand their position and social responsibility, enhance national pride. Everyone's responsibility are very different, and each person as long as efforts will contribute to social development.

\subsection{Create a good campus environment}

Universities need for poor college students to create a good cultural environment on campus, through rich campus activities for students to establish a correct outlook on life and values. Through campus activities, but also can improve the poor college students interpersonal relationships, so that students living on campus more smoothly, through mutual help teachers, classmates, fellow, allows students to integrate into the school environment, students may eliminate spiritual existence pressure.

\section{Conclusion}

After graduating from college students, will enter a wide range of social positions, changes in job content and role in the process, poor college students need the right environment in the face of such changes. In order to achieve the goal of university education must be the spirit of poverty and economic poverty combined with each other to provide opportunities for the poor work-study students, and the need to mobilize the power of the community to provide a better learning environment for poor students, through training in schools, increase poverty comprehensive ability of college students, so that students can better after graduation into the community.

In this paper, Jiangxi College of Humanities and Social Sciences Research (Special Political Education) project "poor college students social adaptation and intervention status quo research" 2014 Year: one (No. SZZX1416) initial results. This subject is funded by Jiangxi college students' ideological and political education research center.

\section{References}

[1]. Jiang Lingling Public and social adaptation of private medical colleges Vocational Students comparative study - in Jinan City [D], Shandong University, 2014 (05): 1-43.

[2]. Li Yanping cultivate social adaptability of students under the guidance of round human development theory [D] Henan Agricultural University, 2013 (06): 1-51.

[3]. Ding Hui social adaptability College Students - Taking Nanjing University of Technology [D] Nanjing University, 2012 (06): 1-49.

[4]. Liu Zhenhua experimental study of college students' social adaptability training to expand - with China University of Geosciences (Beijing) as an example [D] China University of Geosciences (Beijing), 2013 (05): 1-56.

[5]. Ma Zhanju expand research training on social adaptation Affecting College Students - A team cohesion as an intermediary effect [D] Hebei Normal University, 2012 (12): 1-58. 